25

\title{
Engaging New Faculty in Reflection and Inquiry About Their Teaching
}

\author{
Clive Hickson \\ University of Alberta
}

Margaret Wilson

Norquest College

Similar to faculty development offerings at other North American post-secondary institutions, the University of Alberta has delivered orientations and short programs that primarily focus on teaching techniques. While this type of professional development is an important element of enhancing teaching, the literature stresses the need for learning opportunities that encourage reflection as well as time for practice and experimentation. Building upon programs and services already in existence, and in alignment with the University of Alberta's new vision, a formally structured teaching program called the new professor Teaching program was developed and piloted with faculty. The purpose of the program was to engage new professors in the understanding of the academic scholarship of teaching and provide a supported environment for innovation in their teaching. A research study was undertaken to understand how this new program engaged newly hired faculty in reflection and stimulated inquiry about their teaching. The findings of the data collected from the participants indicated that the program was a success and of value. All participants remarked that the program was helpful in developing their teaching repertoire and extending their knowledge of how to become effective teachers.

\section{Introduction}

Historically [teaching in higher education] has been a part of the [academic's] professional role that has relied on passive socialization, on tacit knowledge, and on the benignly collegial assumptions of competence.

Ramsden, 2003, p. xi 
Tn today's academic world, university administrators need to ensure that quality educational experiences are provided to all students enrolled at their institutions. However, the current expectations and demand for faculty members to conduct research and publish findings can contribute to a complex phenomenon for institutions. The pressures of publish or perish placed on faculty members (Booth, 2004; DeRond \& Miller, 2005) at large research intensive universities and the expectations to provide quality learning experiences can create a unique tension. This can be particularly so when, either institutions or even faculty members regard the conducting of research as more important or prestigious than the teaching of courses (Booth, 2004).

Most new faculty members are expected to undertake teaching responsibilities and when they do so they have a direct impact on the learning experiences of the students enrolled in their classes. Unfortunately, the vast majority of these new faculty members have no formal training in the teaching of adult learners (Hickson \& Wilson, 2008). Therefore, it could be argued that institutions need to re-address the imbalance of importance placed on research and teaching and provide greater support for new faculty in order to develop an understanding of how to effectively deliver course content that enhances student learning opportunities.

As enrolment at the University of Alberta continues to grow and the investment costs of developing new faculty remain high, the need for viable programs to assist in the effective delivery of undergraduate courses and support for the development of new faculty seems to be essential.

The engagement of new faculty in the scholarship of teaching is something that all institutions need to be cognizant of and working toward. As Boyer (1990) suggests, such scholarship involves the encouragement of faculty members to constantly reflect upon their current teaching practices, assess ways to help their students learn, and link those reflections with further inquiry.

\section{Faculty Development and the new professor Teaching program}

Similar to faculty development offerings at other
North American post-secondary institutions, most of the programs and services offered by University Teaching Services (UTS) at the University of Alberta have been delivered as short seminars or workshops that focus on teaching techniques. While this type of professional development is an important element of enhancing teaching, the literature stresses the need for learning opportunities that encourage reflection as well as time for practice and experimentation (Brookfield, 1995; Cranton, 1996; Katz \& Henry, 1993). Therefore, it is important to find ways to help faculty members apply the same level of curiousity to their teaching as they have for their research. Just as it is important for students to be active learners, faculty members also need to become active learners in their role as educators (Hickson \& Wilson, 2008). There is a clear need to move beyond focusing on teaching techniques if the aim is to achieve a dynamic learning environment that encourages excellence through thoughtful and reflective instructional practice.

In reaction to these issues, a program called the new professor Teaching program (npTp) was developed by UTS to encourage new faculty to reflect upon and inquire into their own teaching, understand how this reflection and inquiry could impact the learning environment for their students, and engage in understanding the academic scholarship of teaching. Development of the npTp was evidencebased and considered effective practices that impact student learning in higher education. In particular, the ideas and thoughts of Clayton and Ash (2005), Jarvis (1992), and Schonwetter and Narzarko (2005) were recognized as a foundation to develop the program from. Once finalized, the npTp consisted of a series of seminars that addressed teaching and learning issues. The seminars occurred at regular times during the first year of the faculty member's appointment. All the seminars were delivered by selected teaching award winning faculty from a variety of faculties across campus. In order to study the effectiveness of the npTp in achieving these goals for the new faculty members, a research proposal was developed and ethical approval obtained. Funding was obtained through the Teaching and Learning Enhancement Fund at the University of Alberta to support the collection and analysis of data to understand the per- 
ceived effectiveness of the npTp.

\section{The Research Study}

The study design allowed the npTp to be offered for two years. In the first year, a total of 12 participants representing the disciplines of engineering, law, medicine, nursing, and science volunteered to part of the program and the research study. In the second year, eight faculty members chose to be part of the program. Again, the participants were from a variety of faculties including arts, education, and nursing.

In the first year of the research study, the $n p T p$ consisted of a structured series of seminars that were delivered by invited faculty who presented their research and its implications for the teaching and learning environment. Participants were engaged in discussions around the seminar topics and were encouraged, through group discussions and written assignments, to reflect on their own practice and how they might begin to apply the research to their own teaching practice. Table 1 illustrates the types of reflective assignments provided during the $\mathrm{npTp}$ and a description of their content.
Seminar topics were chosen to mirror a teaching framework and support the understanding of teaching as a scholarly activity that follows a carefully considered process. Topics included, for example, Developing a Personal Teaching Philosophy, Instructional Design, Student Learning and Motivation, Integrating Teaching and Research, Understanding Assessment and Evaluation Practices, and the Scholarship of Teaching and Learning. The seminars were delivered in a systematic manner to ensure a coherent understanding of the teaching and learning process. The new faculty members were introduced to the topics through instructional delivery methods that modeled participant engagement with learning materials and were also provided with opportunities to participate in reflective activities.

In the second year of the research study, changes were made to the structure of the npTp based on the feedback provided from the first year's participants. Specifically, two changes were made. First, although seminars were again delivered by invited faculty, a greater portion of time was provided to the participants to discuss and analyze their own personal practices in relation to the information and ideas being presented at the seminar. This change maximized

\section{Table 1}

Examples of Reflective Activities Provided to Participants

\begin{tabular}{|c|c|c|c|}
\hline $\begin{array}{l}\text { Statement of } \\
\text { Teaching Philosophy }\end{array}$ & $\begin{array}{l}\text { Reflections on } \\
\text { Teaching \& Learning }\end{array}$ & $\begin{array}{l}\text { Teaching } \\
\text { Goals Inventory }\end{array}$ & $\begin{array}{l}\text { Adult } \\
\text { Learning Methods }\end{array}$ \\
\hline $\begin{array}{l}\text { Participants were asked } \\
\text { to write what they } \\
\text { valued about teaching, } \\
\text { these thoughts were } \\
\text { then placed in an } \\
\text { envelope and sealed, } \\
\text { after six months of the } \\
\text { npTp the envelope } \\
\text { was returned to the } \\
\text { participants and opened. } \\
\text { These early program } \\
\text { personal thoughts and } \\
\text { ideas were revisited } \\
\text { and then discussed with } \\
\text { other participants. }\end{array}$ & $\begin{array}{l}\text { Participants were } \\
\text { required to complete a } \\
\text { questionnaire that had } \\
\text { them identify: a) the top } \\
\text { three responsibilities } \\
\text { of a university teacher; } \\
\text { and b) the top three } \\
\text { responsibilities of a } \\
\text { university student. } \\
\text { This was followed with } \\
\text { a group style discussion } \\
\text { of thoughts and ideas. }\end{array}$ & $\begin{array}{l}\text { The Angelo and Cross } \\
\text { (1993) Teaching } \\
\text { Goals Inventory tool } \\
\text { was administered. } \\
\text { This was followed } \\
\text { with the participants } \\
\text { being provided with } \\
\text { time for self-reflection } \\
\text { before being asked to } \\
\text { participate in a group } \\
\text { discussion. }\end{array}$ & $\begin{array}{l}\text { The philosophy of adult } \\
\text { education inventory } \\
\text { from Galbraith's (1998) } \\
\text { work was administered. } \\
\text { Time for self-reflection } \\
\text { was allowed before } \\
\text { participants were } \\
\text { asked to compare } \\
\text { their thoughts with } \\
\text { their statement of } \\
\text { teaching philosophy. } \\
\text { This was followed } \\
\text { with the opportunity } \\
\text { for discussion on how } \\
\text { thoughts had changed } \\
\text { (or not). }\end{array}$ \\
\hline
\end{tabular}


the amount of participant engagement. Second, tasks were no longer expected to be completed in the participant's own time and were incorporated into the seminar time where immediate peer feedback was provided. This change allowed for greater and more immediate feedback to the participants which challenged and encouraged self-reflection.

\section{Methods}

This study involved the engagement of participants in reflective activities and the collection of data from questionnaires, interviews, and reflective writing. Descriptions of the types of activities and data collection techniques that were employed are detailed in Tables 1 and 2. Table 1 provides a description of the kind of activities that the participants participated in and completed, while Table 2 indicates the formal data collection techniques. Data was collected from both the first and second year participants of the npTp to determine the overall effect of the program. From this data, it was hoped to understand the lived experience of the new faculty members, their experiences within the npTp, and whether participation in the program was thought to be beneficial.

A mixed methodology was used to understand the perceptions of the participants regarding the effectiveness of the npTp. A Likert-scale questionnaire was developed and administered to participants in order to provide an initial needs analysis, to direct the choice of topic areas to be covered, and the qualitative data collection methods. As Goodard and Foster (2001) suggested the "lived experiences" of neophyte educators cannot be represented nor understood merely through the analysis of Likert-type data. Therefore, in this study, it was decided that, although the collection of quantitative data was important to provide foundational understanding and direction, it has limited value in regards to analysis and interpretation of the perceptions of the participants. Descriptive statistical procedures were used to analyze the quantitative data and provide a base of understanding from which the focus of the qualitative data collection would be developed. It was found that open-ended survey questions and personal interviews could provide the richness of data that would enable the researchers to identify and understand the information that is important in the lives of new faculty. For the identification of qualitative data constructs, themes and patterns were identified to describe and explain the phenomenon being studied (Gall, Gall, \& Borg, 2003).

In a similar manner as most qualitative research studies, the co-investigators asked the formative questions that provided the mid-program feedback. Participants were allowed to return these minute papers anonymously. As well, participants were asked to volunteer a copy of the self-reflective exercises (e.g. Teaching Inventory Goals). Following the completion of the first year of the npTp, exit interviews were conducted by one of the co-investigators of the program. In the second year, the same exit questions were conducted by a graduate research assistant who had been trained to assist with the data collection and analysis. Triangulation was used when considering the themes presented within the qualitative data. The two investigators and the graduate research assistant each reviewed the data, identified themes, and met as a group to determine which themes were evident from the data collected with the different interpretive activities.

Although the presence of the co-investigators

\section{Table 2}

Description of Data Collection Techniques

Mid-Program Feedback

Classroom assessment technique similar to the minute paper that involved self-reflection, this was then followed with a personal interview to probe answers and gain further insight.
Exit Interview

Questions asked during this aspect of the program probed the content and the process of the npTp. 
in the data collection and analysis can raise the issue of potential researcher bias, it is common practice for researchers to undertake such an integral role in qualitative style research. However, the presence of the graduate research assistant did allow for a more 'external' view to be gained and enabled any potential bias to be somewhat lessened. Nevertheless, this is a feature that needs to be recognized and acknowledged.

\section{Results}

The findings of the participant data indicated that they perceived the npTp to be effective in engaging new faculty in reflection of their teaching practice and stimulating inquiry about their teaching. For example, participants identified two classroom activities that were instrumental in stimulating inquiry: asking participants to develop a one page map of their course content and then present that to their colleagues for discussion, and asking participants to de-construct one of their examinations and relate their findings to their course learning outcomes. The discussions were rich, collegial, and stimulated other questions for participants according to the data.

Participants overwhelmingly supported the value of the npTp. All participants remarked that the program was helpful in developing their teaching repertoire and extending their knowledge of student learning, the intricacies of planning for learning, and effective teaching practices. In particular, participants remarked that the opportunities to discuss issues as a group and reflect on personal practice were of great value.

The analysis of the collected data not only identified three main themes that were consistent between the participants but also indicated that the participants concluded that their participation in the new professor teaching program was most beneficial. The three themes were: developing as teachers, having opportunities to discuss issues in a group setting, and reflecting on personal practice.

\section{Developing as teachers...}

"For the first time I really feel as if I am learning about HOW to teach. Consequently, I am not standing in front of my class any more and wondering do the students understand. I know how to find out now!"

"Well, I am a better teacher now. What I mean is, well, I think that I must have been pretty weak before. I really believe that I teach better now. Am I ever glad that I volunteered to part of this project. Thanks!"

"A really, really worthwhile experience. I have become a better teacher by being part of this program."

\section{Having opportunities to discuss issues in a group setting...}

"Just knowing that there were other professors having the same thoughts as me was very comforting. At first it was difficult to say what I was thinking about my teaching but after a while it became a lot easier. When I heard the other members of the group discuss their teaching it made me understand that I could learn from their experiences too."

"Discussing issues in a group was helpful as I did not feel judged and I think everyone felt comfortable sharing as we all knew each other."

\section{Reflecting on personal practice...}

"I think that this is the first time I have ever really thought about teaching. I suppose I never really considered it to be technical or like an art or science, as they say, I suppose I just thought that you just get up in front of everyone and do it. Now I know differently! I think that this is pretty much the first time that I have taken the time to really think about how you teach.” 
"I like to reflect on what I do. The npTp allowed me to do this even more. My reflections over the past year have helped me to improve what I do as a teacher and have made my classes better for students."

\section{Concluding Thoughts}

The data collected from the participants indicated that their involvement in the npTp caused them to reflect upon their practice and stimulated further inquiry about their teaching. From the themes identified, it was clear that the participants welcomed their role in the npTp and thought that the program contributed to their development as a new faculty member. Specifically, they had developed an awareness of how to reflect on and inquire into their own teaching; how reflection and inquiry impacts the learning environment, and how to engage in the academic scholarship of teaching. Post-secondary institutions do invest in their new faculty. Thomas (1997) suggests that by the time tenure is either awarded or denied to a faculty member that institutions have invested between $\$ 500,000$ and $\$ 1,000,000$. Therefore, programs such as the npTp may well be of great value. Also, as new faculty members are expected to undertake teaching responsibilities, such a program can help to ensure that new faculty are provided with support in order to have a positive impact on the learning experiences of the students enrolled in their classes. Supporting new faculty members in the scholarship of teaching is a critical issue. By definition, that scholarship involves reflection on practice, and by providing a safe and collegial environment for faculty to reflect and grow, institutions can ensure that new faculty members receive the support and are provided with the opportunities to develop their knowledge and understanding to effectively deliver course material and become to be the educational leaders of tomorrow!

\section{References}

Angelo, T.A. \& Cross, K.P. (1993). Classroom assessment techniques: $A$ handbook for college teachers. San Francisco: Jossey-Bass.

Booth, A. (2004). Rethinking the scholarly: Developing the scholarship of teaching in history. Arts and Humanities in Higher Education, 3(3) 247-266.

Boyer, E. (1990). Scholarship reconsidered: Priorities of the professoriate. Princeton, NJ: Carnegie Foundation for the Advancement of Teaching.

Brookfield, S. (1995). Becoming a critically reflective teacher. San Francisco: Jossey-Bass.

Clayton, C. \& Ash, S. (2005). Reflection as a key component in faculty development. On the Horizon, ProQuest Education Journals, 13(3), 161-168.

Cranton, P. (1996). Professional development as transformative learning: New perspectives for teachers of adults. San Francisco: Jossey-Bass.

DeRond, M. \& Miller, A.N. (2005). Publish or perish: Bane or boon of academic life. Journal of Management Inquiry, 14(4), 321329.

Galbraith, M. (Ed.). (1998). Adult learning methods: A guide for effective instruction ( $2^{\text {nd }}$ ed.). Malabar, FL: Krieger Publishing.

Gall, M., Gall, J., \& Borg, W. (2003). Education research: An introduction ( $7^{\text {th }}$ ed.). New York: Allyn and Bacon.

Goodard, J.T., \& Foster, R.Y. (2001). The experiences of neophyte teachers: A critical constructivist assessment. Teaching and Teacher Education, 17, 349-365.

Hickson, C. \& Wilson, M. (2008). Engaging new professors in the scholarship of teaching. Hawaii international conference on education published proceedings (pp. 228-237). 
Honolulu, Hawaii: Hawaii International Conference on Education.

Jarvis, D.K., (1992). Improving junior faculty scholarship. New Directions for Teaching and Learning, 50 (Summer), 63-72.

Katz, J. \& Henry M. (1993). Turning professors into teachers: A new approach to faculty development and student learning. Phoenix, AZ: Oryx Press.

Ramsden, P. (2003). Learning to teach in higher education $\left(2^{\text {nd }} \mathrm{ed}\right)$. London: Routledge.

Schonwetter, D.J. \& Narzarko, O. (2005). Meeting the needs of new faculty: Lessons learned from 48 current Canadian new faculty development programs. Paper presented at the $29^{\text {th }}$ Annual Conference of the Society for Teaching and Learning in Higher Education, Charlottetown, PEI.

Thomas, J. R. (1997). Vision and leadership for selecting and mentoring new faculty in higher education. Journal of Physical Education, Recreation, \& Dance, 68(5), 41-46.

\section{Biographies}

Clive Hickson is an Associate Professor at the University of Alberta, where he is a member of the Faculty of Education. Clive has been recognized by both the Faculty of Education and the University of Alberta for his teaching and acts as a Faculty of Education representative on a variety of Alberta Education committees.

Margaret Wilson joined the Centre for Innovation and Development at NorQuest College in January 2008 to develop and implement a new vision for faculty development. For the past five years, Margaret has been the Alberta representative on the STLHE Board of Directors with responsibility for Conference and Events portfolio. She is currently chair of the Alberta Network of Professional and Organizational Development and secretary for the new STLHE College Special Interest Group. 